\title{
Preparation of cattle manure compost using saw dust and rice straw
}

\author{
MM Ali ${ }^{1 *}$, FA Khan ${ }^{2}$, MM Hossain ${ }^{2}$, ANMI Rahman ${ }^{1}$ \\ ${ }^{1}$ Department of Animal Production and Management, Sher-e-Bangla Agricultural University, Dhaka; \\ ${ }^{2}$ Department of Animal Science, Bangladesh Agricultural University, Mymensingh
}

\begin{abstract}
The experiment was carried out to examine the possibilities of making compost by using cattle manure with saw dust and rice straw by three trials in each. The trials were conducted with cattle manure $\left(T_{1}\right)$, cattle manure with saw dust $\left(T_{2}\right)$ and cattle manure with rice straw $\left(T_{3}\right)$. There were three replications in each treatment. The sample from composted materials was collected at 0 and 60 days for proximate analysis. At 0 day, the highest dry matter (DM), organic matter (OM) and crude fiber (CF) were observed in $T_{2}$. The highest crude protein $(C P)$ and ash content were observed in $T_{1}$ while the highest $\mathrm{pH}$ was observed in $\mathrm{T}_{3}$. The carbon nitrogen $(\mathrm{C} / \mathrm{N})$ ratio was the lowest in $\mathrm{T}_{1}$. At 60 days of composting cattle manure the highest $\mathrm{DM}, \mathrm{OM}$ and $\mathrm{CF}$ were observed in $\mathrm{T}_{2}$ comparison with 0 day data. At 60 days of composting the highest $\mathrm{CP}$ and ash content were observed in $\mathrm{T}_{2}$ and the $\mathrm{C} / \mathrm{N}$ ratio and $\mathrm{pH}$ were lowest in $T_{1}$. Therefore, the use of saw dust and rice straw improves quality of cattle manure compost. It may be concluded that proximate composition of all samples at 60 days in $T_{2}$ treatment was acceptable up to the end of composting period. However, $\mathrm{T}_{2}$ was more effective compare to other treatments at 60 days of composting in terms of $\mathrm{DM}, \mathrm{OM}, \mathrm{CP}$, ash content and $\mathrm{pH}$. So, it is recommended that farmers can practice cattle manure composting using saw dust up to 60 days of composting as organic fertilizer.
\end{abstract}

Key words: Cattle manure, composting, proximate composition, rice straw, saw dust

Bangladesh Animal Husbandry Association. All rights reserved.

Bang. J. Anim. Sci. 2015. 44 (1): 64-68

\section{I ntroduction}

In recent years, intensive livestock production has resulted in high density of animals in small areas, producing large quantities of solid waste with relatively insufficient nearby land for application. This has led to environmental concerns including odor pollution, methane emissions, $\mathrm{N}$ and $\mathrm{P}$ pollution of waterways (Tamminga 1992). The high $\mathrm{N}$ and $\mathrm{P}$ discharges lead to eutrophication, and adversely affect the growth and diversity of aquatic life (Morse 1995; Lopez-Real and Baptista 1996). Composting is defined as a biological decomposition and stabilization of organic substrates, under conditions that allow the development of thermophilic temperatures as a result of biologically produced heat, to produce a final product that is stable, free of pathogens and plant seed and can be beneficially applied to land (Haug 1993). The carbon nitrogen $(C / N)$ ratio is one of the important factors affecting composting process and compost quality. In addition to being a source of available and stable nutrients, compost is a source of bacterial and fungal *Corresponding Author: mahabbat01sau@gmail.com diversity that is often lacking in soils that have been used for conventional, chemical agriculture. Compost can be used as a potting media component for container grown transplants. In composting, organic starting materials are modified by decomposition through a wide variety of biological and biochemical processes. Commonly used bulking materials for good composting are saw dust, straw, crop residue and tree leaves. Saw dust has a very fine particle size, providing a good carbon source. However, it is very poor in providing air circulation. It is also quite absorbent, and when moisture fills the spaces, air has a hard time circulating. If using fine materials like saw dust, it will need to be turned frequently or air will need to be forced through the pile which is hard with dense material. Straw (dried grasses) are a good carbon source. Compost contains many essential nutrients and improves soil physical and chemical properties. It without a doubt is a valuable product as compost improves soil organic matter content, nutrient availability, soil aeration, and water holding capacity, and reduces soil bulk 
density. Primary goals of composting have included the safe handling of organic wastes and enhancement of soil's fertility. Compost also can provide a steady supply of nutrients to growing plants and increase the soil's ability to retain essential minerals (Stevenson 1994). When composting processes are not carried out under optimized conditions, there is a risk that pathogens originating from plant and food residues can remain in the compost, which raises concern that pathogens may be carried into agricultural products and the human food. Zucconi et al. (1985) also raised concern about toxic effects from the use of improperly treated waste matter. Due to the lack of proper disposal system, the voluminous manure and excreta are creating environmental and health hazards and foul smell near and adjoining areas of the farms. By some communities' livestock manure and poultry droppings are thrown into fishpond without any treatment and caused water and soil pollution and transmitted diseases to fish and other living things. As a result local communities are complaining against these farms, which in the long run may become threat to the sustainability of livestock and poultry industries. So proper disposal of livestock manure and minimization of environmental pollution are becoming a new challenge for farmers. In Bangladesh situation, few studies on composting by using livestock manure have been done. Moreover different ingredients can be used as a bulking material with livestock manure. Therefore, the present study was undertaken to examine the possibilities of making compost by using cattle manure with saw dust and rice straw.

\section{Materials and Methods}

The experiment was conducted in two phases: The first phase was the preparation of compost and the second phase was laboratory analysis of compost. Preparation of compost and related activities were carried out at the Sheep, Goat and Horse Farm in the Department of Animal Science, Bangladesh Agricultural University (BAU), Mymensingh during the period from 30 October to 30 December, 2011. The laboratory analysis of compost was completed at the laboratory in the Department of Animal Science, Bangladesh Agricultural University, Mymensingh. The experiment was laid out in a complete randomized design. To fulfill the objectives three experiments were conducted e.g., anaerobic composting with only raw cattle manure $\left(T_{1}\right)$, cattle manure with saw dust $\left(T_{2}\right)$, cattle manure with rice straw $\left(\mathrm{T}_{3}\right)$ under soil surface of composting. Sawdust and rice straw were added with manure by maintaining the moisture at $70 \%$. Fifty (50) g sample was collected from each treatment of composting. The sample from composted materials was collected at 0 and 60 days for proximate analysis. In each treatment there were three replications to minimize the experimental errors.

The raw materials were carried into sac and stored in air tight condition, where rain water was not logged. At first, the place was cleaned and then 3 similar pits were prepared whose diameter and depth were 75 and $45 \mathrm{~cm}$, respectively. Polyethylene bags were set at the bottom and side wall of the pits to prevent leaching and water contamination with compost. After collection the sample was mixed properly and divided each sample in 3 parts then $8 \mathrm{~kg}$ saw dust was mixed with one parts and $5 \mathrm{~kg}$ rice straw was mixed with another parts to fix the moisture level at $70 \%$. No treatment was given to the rest of the parts. All treated and untreated raw materials were divided into 3 equal parts and filled the previously marked pits located in the Animal Science Field Laboratory, covered with eight $\mathrm{cm}$ soil layer and kept for composting for 60 days. Pit temperature was $28^{\circ} \mathrm{C}$ to $40^{\circ} \mathrm{C}$ optimum for anaerobic composting. The process of composting emitted very little odor. The samples were taken at 0 day and 60 days for chemical analysis. Samples were prepared from raw materials (cattle manure) just after collection. Again, samples were collected from $T_{1}, T_{2}$ and $T_{3}$ after proper mixing of saw dust and rice straw respectively with raw materials. After 60 days, samples were collected from all composting pits and analyzed. The parameters studied were dry matter (DM), organic matter (OM), crude protein $(C P)$, crude fiber $(C F)$, carbon nitrogen $(C / N)$ ratio, ash and $\mathrm{pH}$. After composting (60 days), analysis was done to compare changes during composting. Analytical procedures were conducted at the Laboratory of Animal Science Department. 


\section{Cattle manure composting with saw dust and rice straw}

The prepared compost from all composting pits were preserve in plastic sac lined inside with airtight poly bags and the open end of the bag was tied tightly to prevent aeration. For $\mathrm{pH}$ determination, two grams of samples from each treatment were taken followed by adding $50 \mathrm{ml}$ distilled water and mixed thoroughly by rigorous stirring. The extracts were filtered through filter paper and $\mathrm{pH}$ of the sample was determined using a laboratory $\mathrm{pH}-\mathrm{mV}$ meter. Representatives samples of cattle manure with $\left(\mathrm{T}_{2}\right.$ and $\left.\mathrm{T}_{3}\right)$ and without $\left(T_{1}\right)$ treatments before and after composting were analyzed for the determination of dry matter (DM) organic matter (OM), crude protein $(C P)$, crude fiber ( $C F)$, ash following the methods of AOAC (1990) at Animal Science laboratory, Bangladesh Agricultural University, Mymensingh. All the samples were analyzed in triplicate and mean values were recorded. The samples were weighed and dried in an oven at a temperature of $105^{\circ} \mathrm{C}$ for 2 days till the constant weight was attained.

After determination of DM, the samples were taken for determination of $\mathrm{OM}$ from $1 \mathrm{~g}$ of sample in a muffle furnace at $550^{\circ} \mathrm{C}$ for 5 hours. The weight of ash was deducted from the DM for estimation of OM.

Nitrogen (N) content of all the samples was determined by Kjeldahl digestion of a $5 \mathrm{~g}$ sample with concentrated $\mathrm{H}_{2} \mathrm{SO}_{4}$ and $1.5 \mathrm{~g}$ mixed catalyst distilled into 2 percent boric acid solution and titrated with $0.1 \mathrm{~N} \mathrm{HCl}$. Crude protein was estimated by multiplying $\mathrm{N}$ content of sample and was added $120 \mathrm{ml}$ of $1.25 \% \mathrm{H}_{2} \mathrm{SO}_{4}$ into a beaker and then placed on the heater for boiling ( 30 min). The volume of the content of the beaker was shacked to the edge of the beaker and after 30 min of boiling the beaker was removed from the heater. The content of the beaker was filtered through a Maslin cloth (Filter cloth) by washing with water for several times until it was free from acid. The acid free sample was then transferred into another beaker and added $120 \mathrm{ml}$ of $1.25 \%$ $\mathrm{NaOH}$ solution to it. Again the beaker with the content was fitted to the condenser was boiled for 30 min maintaining the constant volume of the solution. Then the sample was filtered and washed with distilled water until it was free from alkali. Then the filtrate was transferred in a previously weighed empty dried crucible. Dried and weighed sample was then ignited in a muffle furnace at $550-600^{\circ} \mathrm{C}$ for 5-6 hours. After ignition the weight of sample plus crucible was taken. The crude fiber content of the supplied sample was calculated by subtracting the weight of ignited sample from the weight of acid and alkali treated oven dried sample.

The $\mathrm{C} / \mathrm{N}$ ratio refers to carbon divided by nitrogen. Carbon is calculated from organic matter divided by 1.73 factors and nitrogen from crude protein divided by 5.88 constant factors. Composts that are derived primarily from wood by-products have high carbon to nitrogen ratios unless additional nitrogen is added during the composting process. The analysis of variance was done by using MSTAT and SPSS computer package program for a Completely Randomized Design and differences among the treatment means were determined by the Ducan's Multiple Range Test.

\section{Results and Discussion}

Proximate components of cattle manure compost with saw dust and rice straw was estimated in this experiment for dry matter, moisture, crude protein, crude fiber, ash as well as organic matter, $\mathrm{C} / \mathrm{N}$ ratio and $\mathrm{pH}$. Effect of saw dust and rice straw on cattle manure composting at the period of 0 day and 60 days are presented and discussed in this chapter.

Table 1. Effect of saw dust and rice straw on cattle manure at 0 day

\begin{tabular}{lccc}
\hline \multirow{2}{*}{ Ingredient } & \multicolumn{3}{c}{ Treatment groups (Mean \pm SE) } \\
\cline { 2 - 4 } & $\mathrm{T}_{1}$ & $\mathrm{~T}_{2}$ & $\mathrm{~T}_{3}$ \\
\hline $\mathrm{DM} \%$ & $42.7^{\mathrm{c}} \pm 0.52$ & $43.98^{\mathrm{a}} \pm 0.40$ & $43.06^{\mathrm{b}} \pm 0.23$ \\
$\mathrm{OM} \%$ & $29.61^{\mathrm{c}} \pm 0.37$ & $31.61^{\mathrm{a}} \pm 0.22$ & $30.68^{\mathrm{b}} \pm 0.36$ \\
$\mathrm{CP} \%$ & $15.32^{\mathrm{a}} \pm 0.03$ & $13.88^{\mathrm{b}} \pm 0.18$ & $12.2^{\mathrm{c}} \pm 0.12$ \\
$\mathrm{CF} \%$ & $25.15^{\mathrm{c}} \pm 0.05$ & $28.33^{\mathrm{a}} \pm 0.08$ & $27.42^{\mathrm{b}} \pm 0.02$ \\
Ash\% & $13.26^{\mathrm{a}} \pm 0.15$ & $12.377^{\mathrm{c}} \pm 0.37$ & $12.48^{\mathrm{b}} \pm 0.13$ \\
C/N Ratio & $12.30^{\mathrm{a}} \pm 0.19$ & $14.54^{\mathrm{b}} \pm 0.19$ & $13.13^{\mathrm{c}} \pm 0.40$ \\
pH & $7.30^{\mathrm{b}} \pm 0.03$ & $7.50^{\mathrm{c}} \pm 0.02$ & $7.52^{\mathrm{a}} \pm 0.03$ \\
\hline
\end{tabular}

Mean values in same row with different superscript differed significantly $(p<0.05) ; T_{1}$, only cattle manure; $T_{2}$, cattle manure with saw dust; $T_{3}$, cattle manure with rice straw

Table 1 shows the proximate components and organic matter, $\mathrm{C} / \mathrm{N}$ ratio and $\mathrm{pH}$ at 0 days of 
cattle manure. The DM content differed significantly $(p<0.05)$ among different treatment groups. The highest DM and OM content was observed in $T_{2}$ which was significantly $(p<0.05)$ varied from other treatments at 0 days of cattle manure. The highest $\mathrm{CP}$ content was observed in $T_{1}$ which was significantly $(p<0.05)$ varied from other treatments at 0 days. The highest CF was observed in $T_{2}$ and significantly $(p<0.05)$ different from other treatments. The highest ash content was observed in $\mathrm{T}_{1}$ group. The $\mathrm{C} / \mathrm{N}$ ratio differ significantly $(p<0.05)$ in all treatment groups. The $\mathrm{C} / \mathrm{N}$ ratio was the highest in $\mathrm{T}_{1}$ and the lowest in $\mathrm{T}_{3}$. The highest $\mathrm{pH}$ was observed in $T_{3}$ and significantly $(p<0.05)$ varied from other treatments.

Table 2. Effect of saw dust and rice straw on cattle manure compost at 60 days

\begin{tabular}{lccc}
\hline \multirow{2}{*}{ Component } & \multicolumn{3}{c}{ Treatment groups (Mean \pm SE) } \\
\cline { 2 - 4 } & $\mathrm{T}_{1}$ & $\mathrm{~T}_{2}$ & $\mathrm{~T}_{3}$ \\
\hline $\mathrm{DM} \%$ & $44.2^{\mathrm{c}} \pm 0.23$ & $46.5^{\mathrm{a}} \pm 0.17$ & $44.96^{\mathrm{b}} \pm 0.21$ \\
$\mathrm{OM} \%$ & $30.44^{\mathrm{c}} \pm 0.10$ & $33.00^{\mathrm{a}} \pm 0.37$ & $32.08^{\mathrm{b}} \pm 0.06$ \\
$\mathrm{CP} \%$ & $17.44^{\mathrm{a}} \pm 0.03$ & $19.15^{\mathrm{b}} \pm 0.06$ & $18.06^{\mathrm{c}} \pm 0.18$ \\
$\mathrm{CF} \%$ & $22.08^{\mathrm{c}} \pm 0.017$ & $25.14^{\mathrm{a}} \pm 0.02$ & $24.24^{\mathrm{b}} \pm 0.01$ \\
$\mathrm{Ash} \%$ & $9.10^{\mathrm{a}} \pm 0.21$ & $9.30^{\mathrm{b}} \pm 0.37$ & $9.10^{\mathrm{c}} \pm 0.37$ \\
$\mathrm{C} / \mathrm{N}$ Ratio & $11.6^{\mathrm{a}} \pm 0.03$ & $13.23^{\mathrm{c}} \pm 0.21$ & $11^{\mathrm{b}} \pm 7^{\mathrm{b}} \pm 0.15$ \\
$\mathrm{pH}$ & $6.30^{\mathrm{b}} \pm 0.03$ & $6.40^{\mathrm{c}} \pm 0.02$ & $6.80^{\mathrm{a}} \pm 0.027$ \\
\hline
\end{tabular}

Mean values in same row with different superscript differed significantly $(p<0.05) ; T_{1}$, only cattle manure; $T_{2}$, cattle manure with saw dust; $T_{3}$, cattle manure with rice straw

Table 2 shows the proximate components and organic matter, $\mathrm{C} / \mathrm{N}$ ratio and $\mathrm{pH}$ at 60 days of cattle manure compost. DM content differed significantly $(p<0.05)$ among different treatment groups of cattle manure compost. The highest DM content was observed in $T_{2}$. There were changes of dry matter content in first 60 days. Dry matter content increased with the increase of composting period. The same trends of result was also observed by Adeley and Kitts (1983) and Muller (1982) who reported that dry matter content increased during composting period. Roy (2011) stated that in 60 days of composting DM was gradual decreased in every method and which were also differed among the treatment $(p<0.05)$ and the result contradict to the present findings. The highest OM content was observed in $T_{2}$ which significantly $(p<0.05)$ varied from other treatments at 60 days of cattle manure compost. There was a change in OM values in all samples until 60 days of composting. Roy (2011) stated that OM was gradual decreased in every method and which were also differed among the treatment $(p<0.05)$ and the result contradict to the present findings. The highest $\mathrm{CP}$ content was observed in $T_{1}$ which significantly $(p<0.05)$ varied from other treatments at 60 days of cattle manure compost. It could be assumed that CP content increased with the increase of composting duration also influenced positively by the treatment of saw dust and rice straw. Roy (2011) stated that Crude protein gradually increased in every method (pit composting) and which were also differed among the treatment $(p<0.05)$ and the result is similar to the present findings. The highest $C F$ was observed in $T_{2}$. There was a little change in CF content in all samples until 60 days of composting. The highest ash content was observed in $\mathrm{T}_{1}$. The ash value increase with the increase of composting period, which are in agreement with the findings by Jacob et al. (1997. The $\mathrm{C} / \mathrm{N}$ ratio differ significantly $(p<0.05)$ in all treatment groups. The $\mathrm{C} / \mathrm{N}$ ratio was the highest in $\mathrm{T}_{1}$ and the lowest in $T_{2}$. There was a little change in $\mathrm{C} / \mathrm{N}$ ratio in all samples until 60 days of composting. Sherman (2005) stated that the C:N ratio of 20:1-40:1 is acceptable for composting, while 25:1-30: 1 is preferred and the result within this range. The lowest $\mathrm{pH}$ was observed in $\mathrm{T}_{2}$ and significantly $(p<0.05)$ varied from other treatments. The addition of superphosphate has been shown to conserve nitrogen when used with dairy manure in amounts equal to 2 to 5 percent of the dry weight of manure (Rynk 1992).

\section{Conclusion}

Saw dust and rice straw have a profound effect on cattle manure composting to the point of nutritional aspects. Use of saw dust and rice straw with cattle manure for composting increases the quality of composting. From the result, it may be concluded that proximate composition of all samples at 60 days in saw dust with raw sample was acceptable up to the end of composting period. However, it was more effective compare to only cattle manure and cattle manure with saw dust at 60 days of 
composting in terms of $\mathrm{DM}, \mathrm{OM}, \mathrm{CP}$, ash content and $\mathrm{pH}$. So, it is recommended that farmers can practice cattle manure composting using saw dust up to 60 days of composting as organic fertilizer.

\section{References}

AOAC (1990). Official methods of analysis ( $15^{\text {th }}$ Edition). Association of Official Analytical Chemists, Arlington, Virginia.

Haug RT (1993). The Practical Handbook of Compost Engineering. Lewis Publishers, Boca Raton, Florida, USA.

Jacob JP, Kunkle RS, Trevola RS, Miles RD and Mather FB (1997). Broiler Litter, Part 1: A feed ingredient for ruminants. University of Florida. Cooperative Extension Service. Institute of Food and Agricultural Science.

Lopez-Real J, Baptista M (1996). A preliminary comparative study of three manurecomposting systems and their influence on process parameters and methane emissions. Compost Science and Utilization, 4: 71-82.

Morse D (1995). Environmental considerations of livestock producers. Journal of Animal Science, 73: 2733-2740.
Muller ZO (1982). Feed from animal wastes. Feeding manual. FAO Animal Production and Health. Paper no. 28, Rome, cited from Asian Australasian Journal of Animal Science, 5: 595.

Roy BC (2011). Development of a convenient composting method using rumen content. MS Thesis. Department of Animal Science, Bangladesh Agricultural University, Mymensingh.

Rynk (1992). The addition of superphosphate has been shown to conserve nitrogen when used with dairy manure in amounts equal to 2 to 5 percent of the dry weight of manure.

Sherman R (2005). Large-scale organic materials composting. North Carolina Cooperative Extension Service. P. 1-15.

Stevenson FJ (1994). Humic Chemistry: Genesis, Composition, Reactions. Wiley, New York.

Tamminga S (1992). Nutrition management of dairy cows as a contribution to pollution control. J ournal of Dairy Science, 75: 345357.

Zucconi F Monaco A, Forte M (1985). Phytotoxins during the stabilization of organic matter. In: Gasser JKR, Composting of Agricultural and other Wastes, Elsevier Applied Science Publication, New York, USA. P. 73- 86. 